\title{
NEW RECORDS IN THE ALIEN FLORA OF ROMANIA: EUPHORBIA SERPENS AND E. GLYPTOSPERMA
}

\author{
$\underline{\text { Culiță SÎRBU }}^{1 *}$, Irina ȘUȘNIA (TONE) ${ }^{1}$ \\ ${ }^{1}$ Faculty of Agriculture, University of Agricultural Sciences and Veterinary Medicine \\ "Ion Ionescu de la Brad", Iaşi - Romania \\ * Corresponding author. E-mail: csirbu@uaiasi.ro
}

\begin{abstract}
Our recent field research and revision of some herbarium specimens led us to identify two species of Euphorbia (subgenus Chamaesyce), which we report now for the first time in the alien flora of Romania: Euphorbia serpens Kunth and E. glyptosperma Engelm. The first was collected in the city of Iaşi, north-eastern Romania, in September 2018. The second was collected, during 2005-2015, in several localities from the lower basin of the Siret river (Galați County), as well as from north-eastern Romania, near Ciurea (Iaşi County), but previously erroneously identified as "Euphorbia chamaesyce L.”. Both species, originating in the New World, are xenophytes, more or less naturalized in Europe, perhaps in full process of expansion of their secondary area.
\end{abstract}

Keywords: alien plants, identification key, subgenus Chamaesyce, vascular flora.

\section{Introduction}

Euphorbia L. (Sp. Pl. 1: 450. 1753) is one of the most species-rich genus of flowering plants, with about 2,000 species distributed in all tropical or temperate regions of the world [PAHLEVANI \& RIINA, 2011; BERRY \& al. 2016].

The species of Euphorbia we further refer in the paper belong to the subgenus Chamaesyce Raf., section Anisophyllum Roeper. This clade of Euphorbia includes 300-350 species, most of them originating in the New World [YANG \& BERRY, 2011; BERRY \& al. 2016], that are remarkably distinct within the genus, by their prostrate herbaceous stems with sympodial branching, opposite leaves with asymmetric base and interpetiolar stipules, cyathia axillary, solitary or in small clusters or glomerules (not in pseudoumbels), without obvious bracts; cyathial glands 4, usually with petaloid appendages, seeds without caruncle, and the predominance of $\mathrm{C}_{4}$ photosynthesis [SMITH \& TUTIN, 1968; BENEDÍ \& ORELL, 1992; JINSHUANG \& GILBERT, 2008; PAHLEVANI \& RIINA, 2011; YANG \& BERRY, 2011; BERRY \& al. 2016].

A number of 6 species of subgen. Chamaesyce, sect. Anisophyllum have been reported in the flora of Romania, so far [PRODAN, 1953; OPREA, 2005; CIOCÂRLAN, 2009; SÂRBU \& al. 2013]. Two of them (Euphorbia peplis L. and E. chamaesyce L.) are native in the the Mediterranean region, probably occuring here at the limit of their native area; another one (E. humifusa Willd.) is a casual neophyte originating in the East and Central Asia; the other three species (E. maculata L., E. nutans Lag. and E. prostrata Aiton) are naturalized neophytes originating in North America, and among them at least $E$. maculata can be considered invasive [SÎRBU \& OPREA, 2011]. 
Our recent field research and revision of some herbarium specimens led us to identify two other neophytes species of Euphorbia (subgen. Chamaesyce, sect. Anisophyllum), which we report here for the first time in the flora of Romania.

\section{Material and methods}

Species were identified as a result of our field works (2005-2018), in north-eastern and eastern Romania and by checking of some herbarium specimens collected by the first author during 2005-2015. The geographic coordinates were recorded on the field using an eTrex Legend HCx GPS system. Voucher specimens were deposited in the Herbarium of the University of Agricultural Sciences and Veterinary Medicine Iaşi (IASI). For species identification we used various keys and descriptions published by SMITH \& TUTIN (1968), HÜGIN (1998), JINSHUANG \& GILBERT (2008), PAHLEVANI \& RIINA (2011), BERRY \& al. (2016), RADCLIFFE-SMITH (2018) and many other references as indicate below for each species. The nomenclature of the plant taxa follows SMITH \& TUTIN (1968) and BERRY \& al. (2016).

\section{Results and discussion}

\section{a. Species of Euphorbia reported for the first time in the flora of Romania}

1) Euphorbia serpens Kunth in A. von Humboldt \& al., Nov. Gen. Sp. 2(fol.): 41; 2(qto.): 52. 1817. (Syn.: Chamaesyce serpens (Kunth) Small, Fl. S.E. U.S. [Small]. 709, 1333. 1903)

Distinctive features. It is easily recognizable among other related species of subgenus mainly by the following combination of characters [THELLUNG, 1907; BENEDÍ \& ORELL, 1992; BENEDÍ, 1997; JINSHUANG \& GILBERT, 2008; PAHLEVANI \& RIINA, 2011; SILVA \& al. 2014; WOLF \& KIRÁLY, 2014; BERRY \& al. 2016; RADCLIFFE-SMITH, 2018]: plant entirely glabrous; stems rooting at nodes; leaf-blades entire, suborbicular-ovate, rounded to emarginated at apex, obliquely shallowly cordate at base, without reddish maculae on faces; stipules whitish, united into a triangular scale (subsp. serpens), or almost free, linear, in subsp. fissistipula (Thell.) Hügin (var. fissistipula Thell.); cyathia single, axillary; appendages wider than cyathial glands; seeds gray to brown, smooth.

Identification keys: THELLUNG (1907), BENEDÍ (1997), HERNDON (1993), HÜGIN \& HÜGIN (1997), HÜGIN (1998), PAROLLY \& EREN (2007), RÖTHLISBERGER (2007), JINSHUANG \& GILBERT (2008), HAND (2011), PAHLEVANI \& RIINA (2011), PAHLEVANI \& AKHANI (2011), SILVA \& al. (2014), WOLF \& KIRÁLY (2014), BERRY \& al. (2016).

Iconography: i) drawings - the whole plants, with various details [BENEDÍ, 1997; JINSHUANG \& GILBERT, 2008; PAHLEVANI \& RIINA, 2011; RADCLIFFESMITH, 2018], habitus, seeds and stipules [HÜGIN \& HÜGIN, 1997; HÜGIN, 1998], leaf, nectaries and cyathial appendages [BENEDÍ \& ORELL, 1992]; ii) photos - plants in their habitat [WOLF \& KIRÁLY, 2014; SILVA \& al. 2014; PETROVA, 2018], plant habitus [SILVA \& al. 2014], branches with cyathia [SILVA \& al. 2014; PETROVA, 2018], seeds [HÜGIN, 1998; PAHLEVANI \& AKHANI, 2011; WOLF \& KIRÁLY, 2014]; ii) microscope photos - stipules, hypogynous disc, nectaries and petaloid appendages, capsules 
Culiță SÎRBU \& al.

and seeds [BENEDÍ \& ORELL, 1992], leaf anatomy [BENEDÍ \& ORELL, 1992; NOBARINEZHAD \& al. 2018], mitotic chromosomes and pollen grains [NOBARINEZHAD \& al. 2018].

Origin and general distribution. Native to tropical and subtropical Americas, $E$. serpens was introduced in the Old World (Europe, Asia, Africa, Australia) [JINSHUANG \& GILBERT, 2008; BERRY \& al. 2016], being nowadays a widely naturalized weed in temperate regions [BENEDÍ, 1997].

The first evidence on the presence of this species in Europe dates back from the 19th century. E. serpens subsp. fissistipula was found first, in 1842, in southern France, near Montpellier [THELLUNG, 1907; HÜGIN, 1999], while the typical E. serpens (subsp. serpens) was observed only after about 5 decades, in 1890, in Frankfurt, Germany [HÜGIN, 1999].

Although the subsp. fissistipula was found earlier in Europe, subsequently it was reported as a casual neophyte only in western regions, e.g. in France [THELLUNG, 1907; HÜGIN, 1999], Denmark (since 1974) [HÜGIN, 1999] and Belgium (since 1992) [VERLOOVE, 2006b], while the typical E. serpens seems to be more and more widespread on the continent, and naturalized in many regions (especially in the Mediterranean countries). If towards the end of the last century, E. serpens subsp. serpens has been known only in the Western and Central Europe (the United Kingdom, the Iberian Peninsula, Germany, France, Austria) [CLEMENT \& FOSTER, 1994; HÜGIN \& HÜGIN, 1997; HÜGIN, 1998; HÜGIN, 1999; FISCHER \& al. 2008, DOMINGUES DE ALMEIDA \& FREITAS, 2006; HOHLA, 2013; WOLF \& KIRÁLY, 2014], in the last two decades it has been reported south-eastward from more and more countries, including Switzerland (2004) [RÖTHLISBERGER, 2007], Hungary (2013) [WOLF \& KIRÁLY, 2014], Italy [CELESTIGRAPOW \& al. 2010; LAZZERI, 2015], Greece and Crete [GREUTER \& RAUS, 2007; ARIANOUTSOU \& al. 2010], Cyprus [HAND, 2011], Turkey [PAROLLY \& EREN, 2007] and Bulgaria (2016) [PETROVA, 2018].

Distribution in Romania. We recently identified E. serpens in Romania (Figure

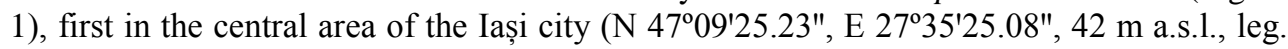

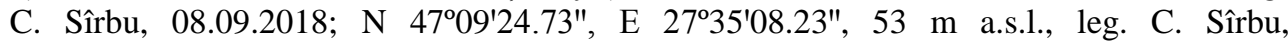
28.09.2018) and subsequently in Bucharest, on the Calea Plevnei Street, near the intersection with the Știrbei Vodă Street (N 44²6'13.92", E 2604'43.68", 77 m a.s.1., leg. C. Sîrbu, 08.11.2018).

All the specimens observed till now in Romania belong to E. serpens subsp. serpens. 


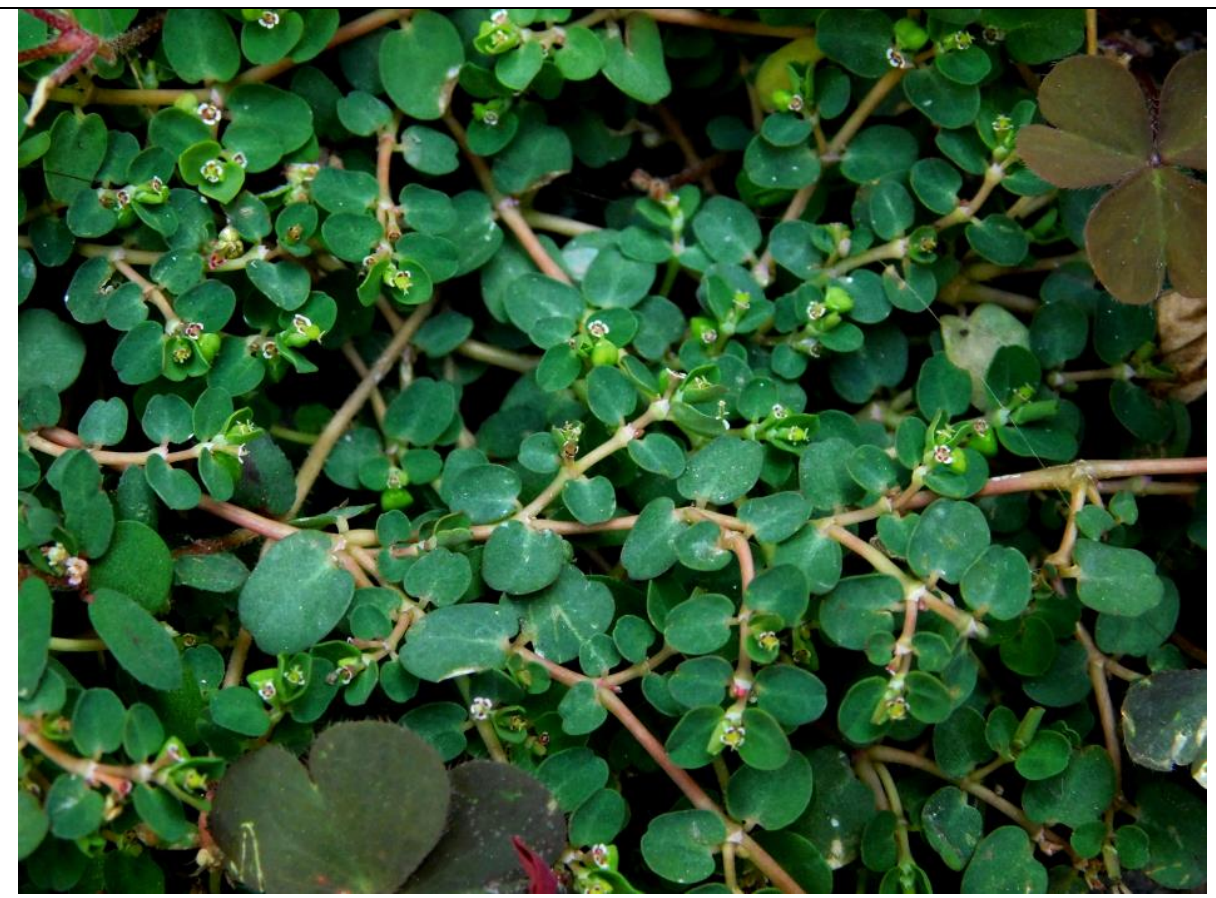

Figure 1. Euphorbia serpens subsp. serpens, as a weed of flower platbands in the central area of the Iași city

Biology and ecology. Euphorbia serpens is a diploid species $(2 \mathrm{n}=22)$ [BENEDI \& ORELL, 1992; BENEDÍ, 1997; NOBARINEZHAD \& al. 2018]. It flourishes and fructifies throughout the year, in warmer areas, or in summer only, in temperate regions [BERRY \& al. 2016]. Most of the plants observed by us not only in September (Iaşi), but also in November (in Iaşi and Bucharest), had numerous mature cyathia and fruits, which shows a quite long period of time in which this species can produce mature seeds in Romania. But among those there were also many young plants, which suggests that E. serpens may have in Romania more than one biological cycle in each growing season as it was reported for the Iberian Peninsula [BENEDI \& ORELL, 1992] and Bulgaria [PETROVA, 2018].

As other C4 photosynthesis plant species, E. serpens is adapted to warm, arid habitats, disturbed by natural or anthropogenic factors [YANG \& BERRY, 2011; WOLF \& KIRÁLY, 2014]. In North America it commonly grows on sandy or well-drained soils, desert scrub, coastal scrub, chaparral, woodlands, sand dunes, prairies, disturbed areas etc. [BERRY \& al. 2016]. It was reported as a weed in ornamental gardens, lawns and roadsides in Iran [PAHLEVANI \& RIINA, 2011], also on sandy places along roads and coastal areas, in China [JINSHUANG \& GILBERT, 2008].

In Europe, E. serpens was reported from various anthropogenic habitats such as: trampled sites often associated with roads (the Iberian Peninsula) (BENEDÍ \& ORELL, 1992; ČARNI \& MUCINA, 1998), flagstone alleys (Hungary), irrigated vegetable gardens (Greece) [GREUTER \& RAUS, 2007], flowerpots [DIRAN, 2016], cemeteries, sidewalks [HÜGIN, 1999; DIRAN, 2016], plant containers, plastic tunnels for plants (Bulgaria) 
Culiță SîRBU \& al.

[PETROVA, 2018], flower beds [HAND, 2011] etc. It commonly participates in the structure of anthropogenic thermophilous plant communities of the order Eragrostietalia $\mathbf{J}$. Tx. ex Poli 1966 [ČARNI \& MUCINA, 1998; WOLF \& KIRÁLY, 2014].

In Romania, we also identified E. serpens in anthropogenic habitats. In the central area of the Iași city it grows as a weed of parterres and flower platbands and along alignments of shrubs and trees, from the park of a shopping center, near the "Culturii" Palace. It had there rich populations forming alone or together with other exotic weeds (e.g. Euphorbia maculata, E. prostrata, Veronica peregrina, Oxalis corniculata etc.) dense patches, stretched to 2-5 $\mathrm{m}^{2}$. In Bucharest the plant grows in some containers with ornamental exotic trees.

Introduction way. According to literature, the long-distance dispersal of $E$. serpens is mainly correlated to human activity (trade and transportation of infested crop seeds or/and soils) [HÜGIN, 1999; PAHLEVANI \& RIINA, 2011; WOLF \& KIRÁLY, 2014] and cannot be interpreted as a result of climatic change [HÜGIN, 1999; WOLF \& KIRÁLY, 2014].

In the green areas of the shopping center from the Iași city, many exotic ornamental plants have been recently introduced (the park was inaugurated in 2012). Therefore we suppose that E. serpens was accidentally introduced there by seeds which might have been present in the contaminated soil imported together with the ornamental plants. The accidental introduction through the contaminated soil together with container exotic plants is more obvious for the smaller population of E. serpens found in Bucharest.

Unfortunately, we have not been able to find out from where the ornamental plants and their growth substrate were brought here. Importation of Euphorbia serpens with container plants from the Mediterranean region to Belgium [HOSTE \& al. 2009] and Switzerland [RÖTHLISBERGER, 2007] was reported recently. This could be the case for plants arrived in Romania, too. PETROVA (2018) also reported recently E. serpens in containers with ornamental plants, in Bulgaria.

2) Euphorbia glyptosperma Engelm. in W. H. Emory, Rep. U.S. Mex. Bound. 2(1): 187. 1859 (Syn.: Chamaesyce glyptosperma (Engelm.) Small, Fl. S.E. U.S. [Small]. 712, 1333. 1903)

Distinctive features. E. glyptosperma differs from the other related species from the flora of Romania by the combination of the following characters [VERLOOVE, 2006; SOMLYAY, 2009; BERRY \& al. 2016; GELTMAN \& MEDVEDEVA, 2017]: plant entirely glabrous; stems prostrate, never rooting at nodes, branches somewhat ascending when young; leaves serrulate, at least to the apex; stipules distinct, linear-subulate; cyathia solitary or in small, cymose clusters at distal nodes; seeds brownish, sharply angular in cross section, apiculate at apex, with 3-4 (-6) prominent transverse ridges.

Iconography: i) drawings - the whole plants, with various details [BERRY \& al. 2016], habitus and seeds [HÜGIN \& HÜGIN, 1997]; ii) photos - plants in their habitat [AYMERICH, 2016], seeds [HÜGIN, 1998; SOMLYAY, 2009; GELTMAN \& MEDVEDEVA, 2017]; capsules and seeds [KIRÁLY \& al. 2009].

Identification keys: HÜGIN \& HÜGIN (1997), HÜGIN (1998), RÖTHLISBERGER (2007), FISCHER \& al. (2008), KIRÁLY \& al. (2009), BÁTORI \& al. (2012), BERRY \& al. (2016), GELTMAN \& MEDVEDEVA (2017). 
Origin and general distribution. It is native in North America, where is one of the most widespread species of the genus [BERRY \& al. 2016], and introduced in Europe [ROUX, 1992; HÜGIN \& STARLINGER, 1997; HÜGIN 1999] and Asia [GELTMAN \& MEDVEDEVA, 2017].

In Europe, E. glyptosperma was found first in Sweden (1911) [GELTMAN \& MEDVEDEVA, 2017], and the Netherlands (1916; 1920) [HÜGIN, 1998] and later in Hungary (in 1957) [SOMLYAY, 2009]. However, being erroneously identified with other related species (E. serpens Kunth, E. rhytisperma (Klotzsch et Garcke) Boiss., E. serpyllifolia Pers., or E. humifusa Willd.), it remained long time unknown on the continent.

Towards the end of the last century, as a result of field works and revisions of older herbarium specimens, E. glyptosperma was first reported from France [ROUX, 1992], Austria (first time collected in 1964), Italy, Switzerland and the former Yugoslavia [HÜGIN \& STARLINGER, 1997; HÜGIN 1999].

In the recent decades the species has been indicated in Hungary, by SOMLYAY (2009) and KIRÁLY \& al. (2009) (naturalized populations), as well as in Belgium (first time collected in 2003) [VERLOOVE, 2006], Spain (2015) [AYMERICH, 2016] and the south-eastern European Russia (1987) [GELTMAN \& MEDVEDEVA, 2017].

Although it was sometimes reported only as a casual neophyte, e.g. Switzerland [RÖTHLISBERGER, 2007], the species is currently naturalized at least in some European countries such as: Hungary [SOMLYAY, 2009; KIRÁLY \& al. 2009], Italy [CELESTIGRAPOW \& al. 2010], Spain [AYMERICH, 2016], and Russia [GELTMAN \& MEDVEDEVA, 2017].

Distribution in Romania. We first collected this species (Figure 2) near the

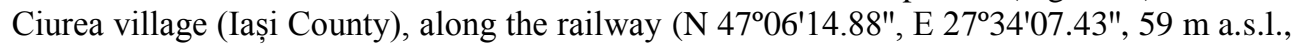
leg. C. Sîrbu, 11.07.2005), and later on in the Galaţi city (railway station, N 45 $27^{\prime} 06.34^{\prime \prime}$, E 28 03'27.25", $7 \mathrm{~m}$ a.s.l., leg. C. Sîrbu, 01.08.2009), as well as on the lower basin of the Siret river, in the villages of Movileni-Şendreni (railway station, N 45²4'11.34", E 2757'52.31", 9 m a.s.1., leg. C. Sîrbu, 01.08.2011) and Șendrenii Vechi (alluvial sands on

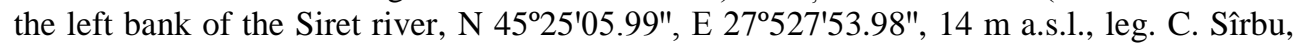
09.09.2015). All specimens collected in the field were originally erroneously identified as Chamaesyce canescens (L.) Prokh.) (i.e. E. chamaesyce L.).

Biology and ecology. Euphorbia glyptosperma is a diploid species $(2 n=22)$ [BERRY \& al. 2016]. It flourishes and fructifies from early summer to autumn [BERRY \& al. 2016]. Specimens collected from Romania in August - September had both flowers and mature fruits and seeds, while the ones collected in early July were in bloom, only.

Like the previous species, E. glyptosperma is a weed of disturbed warm and arid habitats, often on sandy soils. In the native area (North America) it usually grows on river banks, sand prairies, loess hill prairies, meadows, ballast, open disturbed areas, roadsides (in North America) [BERRY \& al. 2016]. In Europe it was found on various habitats such as: potato fields, ruderal places on stony or sandy soils (Hungary) [SOMLYAY, 2009], sand pioneer grasslands (Hungary) [KIRÁLY \& al. 2009], river banks, ruderal places, lawns, roads (Austria) [HÜGIN \& STARLINGER, 1997; ESSL \& RABITSCH, 2002], unloading quays (Belgium) [VERLOOVE, 2006], trampled areas, sidewalks, pavements, river gravels (Italy) [BANFI \& GALASSO, 2010], cemeteries (Italy) [HÜGIN, 1999], ruderal places near ports and roads, but also in more or less natural habitats (Russia) [GELTMAN \& MEDVEDEVA, 2017]. 
Culiță SîRBU \& al.

In Romania, this species has similar preferences for open habitats with sandy or stony soils, disturbed by anthropogenic (train stations, railroads) or natural factors (alluvial sands on the Siret river bank).

Introduction way. Euphorbia glyptosperma has been introduced into Europe most likely with seeds of cereals or other plants imported from North America [VERLOOVE, 2006; GELTMAN \& MEDVEDEVA, 2017]. In Romania it is possible that its introduction have occurred via the fluvial port or the railway station of the Galati city, from where it further spread by road or railway transportation. But, its introduction has not occurred very recently, given that it was first found here more than a decade ago and it grows not only in anthropogenic habitats. but also in those associated with river banks.

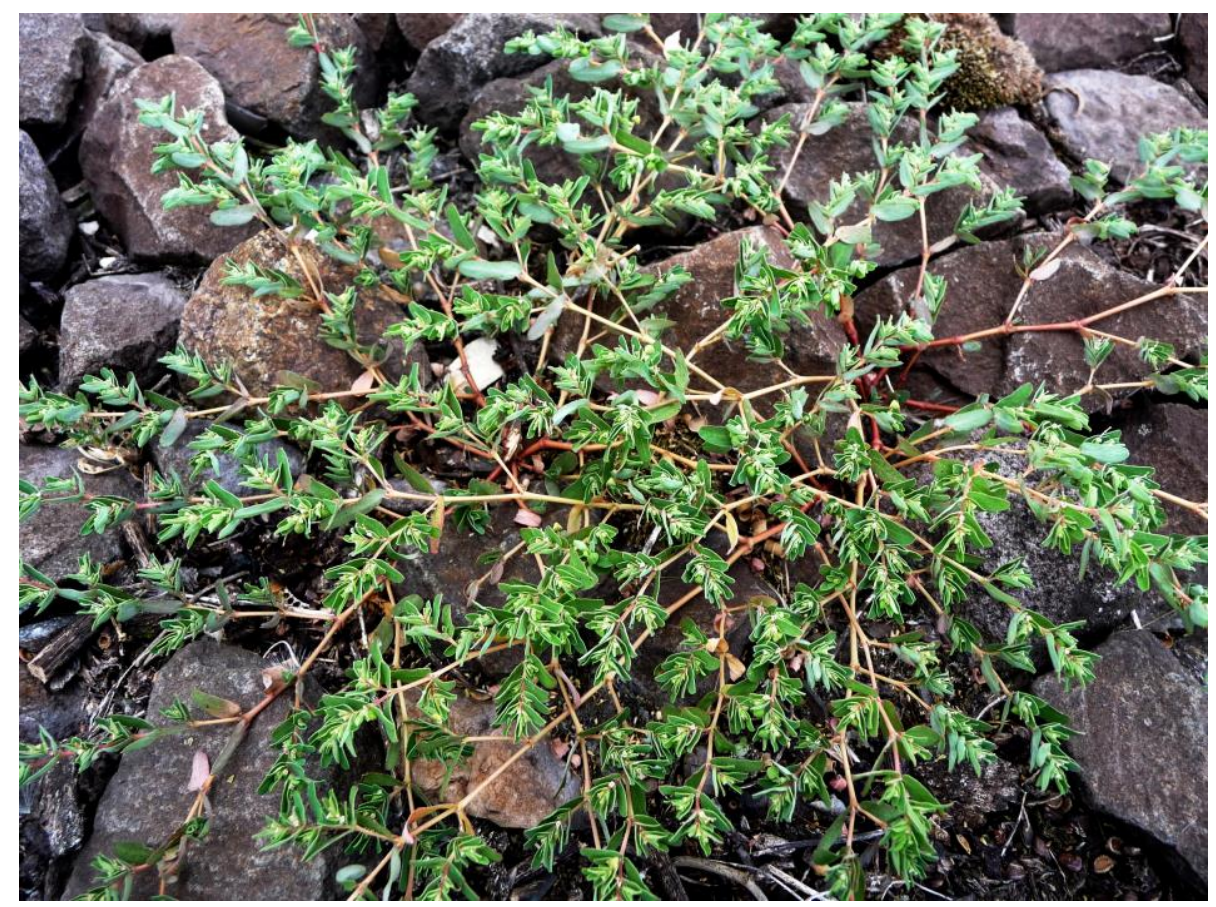

Figure 2. Euphorbia glyptosperma, on the gravels of railway foundation, at the Movileni-Șendreni train station

\section{b. Identification key}

The two species of Euphorbia subgenus Chamaesyce reported here for the first time in the Romania's flora, along with the other six related species previously known (as shown in Introduction) are easily identifiable using the following dichotomous key (see also identification keys indicated above):

1a. Mature seeds smooth (fine reticulated or granulated at high magnification)

1b. Mature seeds irregularly wrinkled, tuberculate-rugulose, or with 3-4 transverse ridges on each face

2a. Plants somewhat fleshy. Capsule of 3-4.5 × 4-5 mm. Seeds of ca. $3 \mathrm{~mm}$ long

Euphorbia peplis L. [Chamaesyce peplis (L.) Prokh.] 
2b. Plants not fleshy. Capsules up to $2 \mathrm{~mm}$ in diameter. Seeds up to $1.5 \mathrm{~mm}$ long .............. 3 3a. Plants glabrous or sparingly pubescent, with prostrate stems, never rooting at nodes. Leaves serrulate at least toward the top. Stipules distinct, linear-subulate. Appendages as large as glands. E. humifusa Willd. [Ch. humifusa (Willd.) Prokh.]

3b. Plants glabrous, usually with repent stems (rooting at nodes) or prostrate (non-rooting) but with conspicuous primordia of adventitious roots at nodes. Leaves entire. Stipules whitish, united into a triangular scale (var. serpens) or almost free, linear (var. fissistipula Thell.). Appendages twice larger than glands

E. serpens Kunth [Ch. serpens (Kunth) Small]

4a. Stems ascending to erect, up to $40-60 \mathrm{~cm}$ high. Longest leaf blades $20-40 \mathrm{~mm}$ long. Cyathia at ends of branches forming in lax, corymbiforme cymes, sometimes solitary. Seeds blackish

E. nutans Lag. [Ch. nutans (Lag.) Small]

4b. Stems prostrate, not so high. Longest leaf blades less than $18 \mathrm{~mm}$. Cyathia solitary or in small axillary pseudoracemose clusters or dense glomerules (not corymbiforme cymes). Seeds greyish or at most brown

5a. Seeds irregularly tuberculate-rugulose, \pm rounded at base. Capsule glabrous to uniform patent-pubescent. E. chamaesyce L. (Ch. canescens (L.) Prokh.) - subsp. chamaesyce: glabrous or pubescent; leaf blade with margin entire or crenate, \pm thickened; appendages about the same size as the glands

- subsp. massiliensis (DC.) Thell. [Ch. massiliensis DC.]: villous; leaf blade with margin serrulate, not thickened; appendages twice larger than the glands

5b. Seeds with 3-4 transverse ridges on each face, \pm truncated at base. Capsule glabrous or hairy, but never uniform patent-pubescent....

6a. Capsule crisped-villous only along keels and toward base (glabrous between keels). Stipules united, triangular-subulate...... E. prostrata Aiton [Ch. prostrata (Aiton) Small]

6b. Capsule either entirely glabrous or uniformly appressed hairy. Stipules distinct, linearsubulate

7a. Stems and leaves sericeous or villous. Capsules uniformly appressed hairy (sericeous). Seeds rounded at apex, with 3-4 low, transverse ridges. Glands green to yellow-green, turning pink with age, usually \pm unequal ....... E. maculata L. [Ch. maculata (L.) Small]

7b. Stems, leaves and capsules glabrous. Seeds apiculate at apex, with 3-4 (-6) prominent transverse ridges. Glands red to purple, usually \pm equal

E. glyptosperma [Ch. glyptosperma (Engelm.) Small]

\section{Conclusions}

Two species of Euphorbia L. (sugenus Chamaesyce Raf., section Anisophyllum Roeper) are reported here for the first time in the spontaneous flora of Romania: Euphorbia serpens Kunth and E. glyptosperma Engelm.

Both species, originating in the New World, are xenophytes, more or less naturalized in Europe, perhaps in full process of expansion of their secondary area. 


\section{References}

ARIANOUTSOU M., BAZOS I., DELIPETROU P. \& KOKKORIS Y. 2010. The alien flora of Greece: taxonomy, life traits and habitat preferences. Biol. Invasions. 12: 3525-3549.

AYMERICH P. 2016. Contribució al coneixement de la flora al·lòctona del nord i el centre de Catalunya. Orsis. 30: 11-40.

BANFI E. \& GALASSO G. (eds.). 2010. La flora esotica lombarda. Milano: Museo di Storia Naturale di Milano, 273 pp.

BÁTORI Z., ERDÖS L. \& SOMLYAY L. 2012. Euphorbia prostrata (Euphorbiaceae), a new alien in the Carpathian Basin. Acta Bot. Hung. 54(3): 235-243.

BENEDÍ C. \& ORELL J. J. 1992. Taxonomy of the genus Chamaesyce S. F. Gray (Euphorbiaceae) in the Iberian Peninsula and the Balearic Islands. Collectanea Bot. 2: 9-55.

BENEDÍ C. 1997. Chamaesyce Gray. pp. 286-297. In: Castroviejo S. \& al. (eds.), Flora iberica, Vol. 8. Madrid: Real Jardín Botánico, C. S. I. C. Madrid.

BERRY P. E., PEIRSON J. A., MORAWETZ J. J., STEINMANN V. W., RIINA R., YANG Y., GELTMAN D., \& CACHO N. I. 2016. Euphorbia. pp. 240-324. In: Flora of North America Editorial Committee (eds.), Flora of North America, North of Mexico, Vol. 12. New York and Oxford: Oxford University Press.

ČARNI A. \& MUCINA L. 1998. Vegetation of trampled soil dominated by C4 plants in Europe. J. Veg. Sci. 9(1): 45-56.

CELESTI-GRAPOW L., PRETTO F., CARLI E. \& BLASI C. 2010. Flora vascolare alloctona e invasiva delle regioni d'Italia. Roma: Università degli Studi di Roma, La Sapienza, 208 pp.

CIOCÂRLAN V. 2009. Flora ilustrată a României. Pteridophyta et Spermatophyta (ed. III). Bucureşti: Edit. Ceres, $1141 \mathrm{pp}$.

CLEMENT E. J. \& FOSTER M. C. 1994. Alien plants of the British Isles: a provisional catalogue of vascular plants (excluding grasses). London: Bot. Soc. British Isles, $590 \mathrm{pp}$.

DIRAN R. 2016. Beiträge zur Adventivflora von Wien und Niederösterreich. Neilreichia. 8: 27-39.

DOMINGUES de ALMEIDA J. \& FREITAS H. 2006. Exotic naturalized flora of continental Portugal - A reassessment. Bot. Comp. 30: 117-130.

ESSL F. \& RABITSCH W. 2002. Neobiota in Österreich. Wien: Umweltbundesamt, 432 pp.

FISCHER M. A., OSWALD K. \& ADLER W. 2008. Excursionflora für Österreich Liechtenstein Südtirol, 3 Aufl. Linz: Biologiezentrum der Oberösterreichischen Landesmuseen, 1392 pp.

GELTMAN D. V. \& MEDVEDEVA N. A. 2017. Euphorbia glyptosperma (Euphorbiaceae), an alien species new for the flora of Russia. Nov. Syst. Plant. Vasc. 48: 131-135.

GREUTER W. \& RAUS Th. (ed.) 2007. Med-Checklist Notulae, 26. Willdenowia. 37: 435-444.

HAND R. (ed.). 2011. Supplementary notes to the flora of Cyprus, VII. Willdenowia. 41: 341- 355.

HERNDON A. 1993. Notes on Chamaesyce (Euphorbiaceae) in Florida. Rhodora. 95: 352-368.

HOHLA M. 2013. Eragrostis amurensis, Euphorbia serpens und Lepidium latifolium - neu für Oberösterreich, sowie weitere Beiträge zur Flora Österreichs. Stapfia. 99: 35-51.

HOSTE I., VERLOOVE F., NAGELS C., ANDRIESSEN L. \& LAMBINON J. 2009. De adventievenflora van in België ingevoerde mediterrane containerplanten. Dumortiera. 97: 1-16.

HÜGIN G. 1998. Die Gattung Chamaesyce in Europa. Feddes Repertorium. 109: 189-223.

HÜGIN G. 1999. Verbreitung und Ökologie der Gattung Chamaesyce in Mitteleuropa, Oberitalien und Südfrankreich. Feddes Repertorium. 110: 225-264.

HÜGIN G. \& HÜGIN H. 1997. Die Gattung Chamaesyce in Deutschland. Bestimmungsschlüssel, Wuchsorte, Fundortskarten und Fragen zur Einbürgerung. Ber. Bayer. Bot. Ges. 68: 103-121.

HUGIN G. \& STARLINGER F. 1997. Erstnachweis für Chamaesyce glyptosperma in Mitteleuropa (mit Berücksichtigung der übrigen europaischen Vorkommen). Flor. Rundbriefe. 31(2): 112-117.

JINSHUANG M. \& GILBERT M. G. 2008. Euphorbia Linnaeus, Sp. Pl. 1: 450. 1753. pp. 288-313. In: Wu W. Z. Y., Raven P. H. \& Hong D. Y. (red.), Flora of China, Vol. 11. Oxalidaceae through Aceraceae. Science Press, Beijing, Missouri Botanical Garden Press, St. Louis. http://flora.huh.harvard.edu/china/PDF/PDF11/Euphorbia.pdf

KIRÁLY G., BARANYAI-NAGY A., KEREKES S., KIRÁLY A. \& KORDA M. 2009. Kiegészítések a magyar adventív-flóra ismeretéhez IV. Flora Pan., J. Phytogeogr. Tax. 7: 3-31.

LAZZERI V. 2015. The alien vascular flora of Tuscany (Italy): update and analysis. Q. Mus. Stor. Nat. Livorno. 26: $43-78$.

NOBARINEZHAD M. H., PAKRAVAN M. \& PAHLEVANI A. 2018. A biosystematic study of Euphorbia subgenus Chamaesyce (Euphorbiaceae) in Iran. Phytotaxa. 360(1): 179-200. 


\section{NEW RECORDS IN THE ALIEN FLORA OF ROMANIA: EUPHORBIA SERPENS ...}

OPREA A. 2005. Lista critică a plantelor vasculare din România. Iaşi: Edit. Univ. "Alexandru Ioan Cuza”, 668 pp.

PAHLEVANI A. H. \& AKHANI H. 2011. Seed morphology of Iranian annual species of Euphorbia (Euphorbiaceae). Bot. J. Linnean Soc. 167: 212-234.

PAHLEVANI A. H. \& RIINA R. 2011. A synopsis of Euphorbia subgen. Chamaesyce (Euphorbiaceae) in Iran. Ann. Bot. Fen. 48: 304-316.

PAROLLY G. \& EREN Ö. (ed.). 2007. Contributions to the flora of Turkey, 2. Willdenowia. 37: 243-271.

PETROVA A. S. 2018. Amaranthus viridis and Euphorbia serpens, new alien species records for the flora of Bulgaria. C. R. Acad. Bulgare Sci. 71(1): 46-53.

PRODAN I. 1953. Fam. Euphorbiaceae J. St. Hill., pp. 295-373. In: Săvulescu T. (ed.), Flora R. P. Române. Vol. 2. București: Edit. Acad. R. P. Române.

RADCLIFFE-SMITH A. 2018. Euphorbia L., in Flora of Pakistan Editorial Committee (eds.): http://www.efloras.org/florataxon.aspx?flora_id=5\&taxon_id=242321518 [accessed on internet, 01.11.2018].

RESSÉGUIER P. 2010. Die Verbreitung der Gattung Chamaesyce auf den Friedhöfen des Landkreises MainSpessart, Bayern. Forum Geobot. 4: 42-46.

RÖTHLISBERGER J. 2007. Aktuelle Verbreitung der Gattung Chamaesyce (Euphorbiaceae) in der Schweiz. Bauhinia. 20: 19-33.

ROUX J. P. 1992. Euphorbia glyptosperma Engelm., taxon nouveau pour la flore de France. Mond. Pl. 443: 4-8.

SÂRBU I., ȘTEFAN N. \& OPREA A. 2013. Plante vasculare din România. Determinator ilustrat de teren. București: Victor B Victor, $1317 \mathrm{pp}$.

SILVA O. L. M., CORDEIRO I. \& ROSSI CARUZO M. B. 2014. Synopsis of Euphorbia (Euphorbiaceae) in the state of São Paulo, Brazil. Phytotaxa. 181(4): 193-215.

SîRBU C. \& OPREA A. 2011. Plante adventive în flora României. Iași: Edit. "Ion Ionescu de la Brad”, 733 pp.

SMITH A. R. \& TUTIN T. G. 1968. Euphorbia L. pp. 213-226. In: Tutin T. G. et al. (Eds.), Flora Europaea, Vol. 2, Cambridge: Cambridge Univ. Press.

SOMLYAY L. 2009. Occurrence of Chamaesyce glyptosperma, and a survey of the genus Chamaesyce (Euphorbiaceae) in Hungary. Ann. Hist.-Nat. Mus. Nat. Hung. 101: 23-32.

THELLUNG A. 1907. Die in Europa bis jetzt beobachteten Euphorbia Arten der Sektion Anisophyllum. Bull. l'Herb. Boissier, 2, sér. 7(9): 741-772.

VERLOOVE F. 2006a. Graanadventieven nieuw voor de Belgische flora, hoofdzakelijk in de periode 2001-2003. Dumortiera. 88: 1-6.

VERLOOVE F. 2006b. Catalogue of neophytes in Belgium (1800-2005). Meise: National Botanic Garden of Belgium, 89 pp.

WOLF M. \& KIRÁLY G. 2014. Euphorbia serpens (Euphorbiaceae), a new alien species in Hungary. Acta Bot. Hung. 56: 243-250.

YANG Y. \& BERRY P. E. 2011. Phylogenetics of the Chamaesyce clade (Euphorbia, Euphorbiaceae): reticulate evolution and long-distance dispersal in a prominent $\mathrm{C}_{4}$ lineage. Am. J. Bot. 98(9): 1486-1503.

\section{How to cite this article:}

SÎRBU C. \& ȘUȘNIA (TONE) I. 2018. New records in the alien flora of Romania: Euphorbia serpens and E. glyptosperma. J. Plant Develop. 25: 135-144. https://doi.org/10.33628/jpd.2018.25.1.135 